\title{
Analisis Kepemimpinan Partisipatif dalam Pengendalian Kebakaran Hutan dan Lahan
}

\author{
Desie Andreastuti
}

\begin{abstract}
Tropical forests in Palangka Rraya city is a tremendous asset givenin view of the forest can provide economic benefits as a foreigPendapatan Asli Daerah (PAD) in addition it is also the sector with the most potential as a source of livelihood and life for society and private plantation companies. However, the existence of forests are currently threatened due to forest areas that were once green became barren and the barren region that is mainly caused by human activity that is that is doing the destruction and land by burningburning the land. Land and forest fires occur each year into problems and threats faced by the multidimensional impact forests. In order For to supporting local government in realizing the land and forest fire control, based on the Regional RegulationPeraturan Pemerintah No. 7 of 2003 is related to the preparation of the land and forest fire control and decision of the Mayor of Palangkaraya No. 11 of 2008 while the duties and functions of the head of Head of the Environment AgencyBadan Lingkungan Hidup (BLH) by Peraturan WalikotaMayor Regulation Palangkaraya No. 17 of 2012 on job descriptions positions of Chairman of the Environment AgencyBLH Palangkaraya is formulating operational policy body, controlling, developing, organizinge, coordinating $e$ and providinge technical services in the field of environmental management are integrated with the together-together relevant agencies in accordance with the provisions and applicable laws.the laws that apply. This study will explore participatory leadership style used by the Head of BLH Palangkaraya in control of land and forest fires. Efforts made by the Head of BLH Palangkaraya is to involve members of the organization in BLH Palangkaraya to be active to control land and forest fires.
\end{abstract}

\section{Keywords:}

forest fires; leadership; participative leadership.

\begin{abstract}
Abstrak
Hutan tropis di Kota Palangka Raya merupakan aset yang luar biasa mengingat hutan dapat memberikan manfaat ekonomis sebagai penyumbang devisa dan Pendapatan Asli Daerah (PAD) selain itu juga merupakan sektor yang paling potensial sebagai sumber mata pencaharian dan kehidupan bagi masyarakat maupun perusahaan perkebunan swasta. Namun keberadaan hutan saat ini terancam karena kawasan hutan yang dulunya hijau menjadi kawasan yang tandus dan gundul yang sebagian besar diakibatkan oleh ulah manusia yang melakukan pengerusakan hutan dan lahan dengan pembakaran. Kebakaran hutan dan lahan yang setiap tahunnya terjadi menjadi masalah dan ancaman yang dihadapi oleh hutan yang berdampak multidimensi. Dalam rangka mendukung pemerintah daerah dalam mewujudkan pengendalian kebakaran hutan dan lahan, berdasarkan Peraturan Daerah Nomor 7 Tahun 2003 yaitu terkait persiapan dalam pengendalian kebakaran hutan dan lahan dan keputusan Walikota Palangka Raya Nomor 11 Tahun 2008 sedangkan tugas dan fungsi Kepala Badan Lingkungan Hidup (BLH) menurut Peraturan Walikota
\end{abstract}

\footnotetext{
- Dosen Jurusan Administrasi Negara Universitas Palangka Raya.

Email: desiandreaSJ@yahoo.com
} 
Palangka Raya Nomor 17 Tahun 2012 tentang uraian tugas jabatan Kepala BLH Kota Palangka Raya adalah merumuskan kebijakan operasional badan, mengendalikan, membina, mengatur, mengkoordinasikan dan memberikan pelayanan teknis di bidang penanganan lingkungan hidup secara terpadu bersama - sama instansi terkait sesuai dengan ketentuan dan perundang undangan yang berlaku.

\section{Kata kunci:}

kebakaran hutan; pemimpin; kepemimpinan partisipatif.

\section{Pendahuluan}

Hutan tropis di Kalimantan Tengah yang dikenal oleh dunia sebagai hutan hujan tropis (rain forest) atau "Heart of Borneo" merupakan aset yang luar biasa karena memberikan manfaat ekonomis sebagai penyumbang devisa dan pendapatan asli daerah (PAD) yang diperlukan bagi kelangsungan pembangunan bahkan berjasa bagi lingkungan dan menopang kehidupan di muka bumi. Di era otonomi daerah Kepala Daerah dituntut untuk mampu meningkatkan PAD dari sumber daya alam yang dimiliki, termasuk sektor kehutanan.

Namun keberadaan hutan di Indonesia, termasuk di Kalimantan Tengah, saat ini terancam karena kawasan hutan yang dulunya hijau menjadi kawasan yang tandus dan gundul yang sebagian besar diakibatkan pengrusakan hutan dan lahan dengan pembakaran. Kebakaran hutan dan lahan terjadi hampir setiap tahun di sejumlah daerah di Indonesia. Di Kalimantan Tengah khususnya kota Palangka Raya kebakaran hutan dan lahan menjadi masalah lingkungan hidup yang tidak hanya disebabkan oleh faktor-faktor alam seperti gambut tetapi juga ulah manusia pada saat pembukaan lahan.

Dalam memperhitungkan biaya, pembukaan hutan atau land clearing dengan cara membakar memang relatif murah. Cara pembukaan hutan dengan pembakaran ini sudah dilakukan sejak dahulu kala. Akan tetapi, akhir-akhir ini dampak negatif yang ditimbulkan terhadap lingkungan hidup semakin mengkhawatirkan. Pembakaran lahan yang tidak terkendali pada musim kemarau menyebabkan kebakaran hutan meluas dan menyebar dengan cepat. Ini sangat merugikan daerah sekitar lokasi terjadinya kebakaran, bahkan dapat meluas ke areal lain yang tidak direncanakan. Menurut data dari BLH Kota Palangka Raya pada bulan Agustus 2013 untuk wilayah Kota Palangka Raya sudah terdapat 109 titik api atau hot spot. Jumlah titik api ini sendiri diperkirakan akan terus bertambah mengingat musim kemarau di wilayah Kalimantan Tengah khususnya kota Palangka Raya yang kering.

Kebakaran hutan telah menyebabkan kabut asap yang membuat buruknya jarak pandang pada pagi hari apalagi di malam hari. Hal ini menganggu perhubungan darat, laut dan udara yang kemudian membawa dampak ekonomi dimana harga barang kebutuhan menjadi sangat mahal. Dalam aspek ekologis kebakaran hutan menyebabkan kerusakan ekosistem hutan dan menganggu lingkung global. Dampak lainnya adalah terganggunya kesehatan masyarakat di beberapa wilayah sekitar seperti iritasi mata, ISPA, bronchitis, asma, sesak nafas dan berbagai penyakit lainnya. Dalam bidang pemerintahan pun terjadi gangguan pelayanan akibat banyak pegawai pemerintahan yang tidak bisa masuk kerja.

Pemerintah Provinsi Kalimantan Tengah khususnya Kota Palangka Raya telah melakukan berbagai upaya meningkatkan pegendalian terhadap bencana kebakaran hutan dan lahan. Berbagai bentuk kegiatan telah dilakukan untuk pengendalian kebakaran hutan berdasarkan Instruksi Presiden Republik Indonesia Nomor 16 tahun 2011 tentang Peningkatan Pengendalian Kebakaran Hutan dan Lahan, Peraturan Daerah 
Provinsi Kalimantan Tengah Nomor 5 tahun 2003 tentang Pengendalian Kebakaran Hutan dan Lahan, Peraturan Gubernur Kalimantan Tengah Nomor 52 tahun 2008 tentang Pedoman Pembukaan Lahan dan Pekarangan bagi Masyarakat di Kalimantan Tengah dan Peraturan daerah Kota Palangka Raya Nomor 07 tahun 2003 tentang Pencegahan dan Penanggulangan Kebakaran Hutan dan Lahan di wilayah Kota Palangka Raya. Pemerintah Kota Palangka Raya telah melakukan koordinasi antara instansi terkait dalam pengendalian kebakaran hutan dan lahan di Kota Palangka Raya. Pengendalian kebakaran hutan dan lahan menurut Peraturan Daerah Provinsi Kalimantan Tengah adalah upaya pencegahan dan penanggulangan serta pemulihan atau pencemaran lingkungan hidup yang berkaitan dengan kebakaran hutan dan lahan. Organisasi-organisasi yang turut dalam melakukan upaya pengendalian kebakaran hutan dan lahan adalah BLH Kota Palangka Raya bersama instansi terkait lainnya yaitu Dinas Kehutanan, Badan KonservasiSumber Daya Alam (BKSDA) dan Badan Penanggulangan Bencana Daerah (BPBD). Hal ini penting mengingat kebijakan dan upaya yang dilakukan terkait dengan pengendalian kebakaran hutan dan lahan tidak terlepas dari peran para pemimpin organisasi atau instansi yang terkait dalam membina, mengatur, mengkoordinasikan dan pengambilan keputusan.

Namun kebijakan yang ada tersebut belum mampu mengatasi kebakaran hutan dan lahan karena hot spot dari kebakaran hutan dan lahan masih dalam jumlah yang besar. Hal ini berdasarkan hasil laporan dari Satelit NOAA (North Oceanic and Atmospheric Administration) yang mencatat kurun waktu sepekan yaitu tanggal 1-7 September 2014, ditemukan 427 hotspot di Kalimantan Tengah. ${ }^{1}$

1 Eka Putra, Ananda. (2014). Dalam Sepekan, Terpantau 427 Titik Panas di Kalteng. (Online), (http://regional. kompas.com/read/2014/09/08/14333991/Dalam. Sepekan.Terpantau.427.Titik.Panas.di.Kalteng)
Hutan merupakan sektor yang paling potensial sebagai sumber mata pencaharian dan kehidupan bagi masyarakat maupun perusahaan perkebunan swasta. Namun demikian, hutan juga dapat menimbulkan banyak persoalan akibat ketidakmampuan mengendalikan kebakaran hutan dan lahan. Hal ini disebabkan oleh beberapa faktor. Diantaranya adalah kerjasama dalam pengendalian kebakaran hutan dan lahan belum optimal disebabkan oleh perbedaan orientasi kelembagaan antara beberapa pihak terkait yang berdampak pada munculnya ego-sektoral. Selain itu, terdapat perbedaan orientasi pola hubungan dalam upaya konservasi hutan yang dilakukan pemerintah yang bersinggungan dengan kepentingan kehidupan masyarakat lokal dan kepentingan pihak perusahaan. Berikutnya, upaya pengendalian kebakaran hutan dan lahan yang kurang efektif sehingga sekalipun sudah ada regulasi tetapi perusahaanperusahaan swasta maupun masyarakat masih melakukan pembukaan lahan dengan cara membakar hutan.

BLH menjadi salah satu instansi yang juga turut melakukan pengendalian kebakaran hutan dan lahan berdasarkan Peraturan Daerah Nomor 7 Tahun 2003. BLH Kota Palangka Raya memiliki peran penting dalam pengendalian kebakaran hutan dan lahan karena dampak dari kebakaran hutan dan lahan yang mengakibatkan kerusakan dan pencemaran lingkungan hidup berdampak luas terhadap lingkungan dan ekosistem yang ada didalamnya. Sedangkan tugas dan fungsi Kepala BLH menurut Peraturan Walikota Palangka Raya Nomor 17 Tahun 2012 tentang Uraian Tugas Jabatan Kepala BLH kota Palangka Raya adalah merumuskan kebijakan operasional badan, mengendalikan, membina, mengatur, mengkoordinasikan dan memberikan pelayanan teknis di bidang penanganan lingkungan hidup termasuk pengendalian kebakaran hutan dan lahan secara terpadu bersama-sama instansi terkait 
sesuai dengan ketentuan dan perundang undangan yang berlaku.

BLH Kota Palangka Raya dalam mengendalikan kebakaran hutan dan lahan tersebut tidak terlepas dari peran yang dilakukan oleh Kepala BLH sebagai pemimpin untuk memecah kebuntuan, konflik dan permasalahan dalam pengendalian kebakaran hutan dan lahan. Meskipun memiliki posisi sebagai seorang pemimpin hendaknya Kepala BLHmau menerima masukan dari pihak lain terutama yang berdampak terhadap kepentingan orang banyak serta turut langsung terlibat dalam pengendalian kebakaran hutan dan lahan. Keberadaan Kepala BLH Kota Palangka Raya sebagai pemimpin sangat dibutuhkan untuk membawa organisasi mampu mencapai tujuan yang diinginkan. Berbagai gaya kepemimpinan akan mewarnai perilaku seorang pemimpin dalam menjalankan tugasnya. Bagaimanapun juga gaya kepemimpinan seseorang tentunya akan diarahkan untuk kepentingan bersama yaitu kepentingan anggota dan termasuk pihak diluar organisasinya. Kepemimpinan seseorang dapat mencerminkan karakter pribadinya. Selain itu, gaya kepemimpinannya juga akan berpengaruh terhadap pengambilan keputusan yang dilakukannya. Dengan adanya kepemimpinan partisipatif yang dilakukan oleh Kepala BLH Kota Palangka Raya diharapkan mampu mengoptimalkan proses pengendalian kebakaran hutan dan lahan serta mampu mengatasi kendala yang dihadapi dalam melaksanakan upaya pengendalian kebakaran hutan dan lahan.

Penelitian-penelitian terdahulu tentang pengendalian kebakaran hutan dan lahan telah banyak dilakukan. Hasil penelitian terdahulu yang relevan dapat dijadikan perbandingan oleh peneliti dalam memahami tentang upaya pengendalian kebakaran hutan dan lahan. Penelitian-penelitian terdahulu tersebut dapat menegaskan perbedaan penelitian yang peneliti lakukan dengan penelitian-penelitian terdahulu yang sudah ada. Penelitian terdahulu tentang upaya pengendalian kebakaran hutan dan lahan bahwa perlu adanya evaluasi dan perbaikan kebijakan dalam pengendalian kebakaran hutan dan lahan. Selain itu juga perlu keselerasan tindakan dari masing-masing anggota organisasi ataupun dengan pihak organisasi terkait lainnya baik lembaga formal maupun pihak swasta atau perusahaan, dan masyarakat. Hal ini diperlukan agar tercipta hubungan-hubungan yang harmonis yang didasarkan pada kepentingan-kepentingan bersama. (Ikwhanuddin Mawardi dan Sudaryono,2008; Yunyta Rusmond, 2008; Febri Yuliani, 2011; Acep Akbar, 2012 ).

Penelitian yang penulis lakukan berbeda dengan beberapa penelitian yang telah dilakukan sebelumnya. Penelitian ini lebih fokus pada upaya yang dilakukan oleh pemimpin organisasi terkait dalam pengendalian kebakaran hutan dan lahan dalam hal ini yaitu Kepala BLH Kota Palangka Raya dengan menggunakan kepemimpinan partisipatif dalam pengendalian kebakaran hutan dan lahan. Aspek yang dilihat dalam penelitian ini yaitu gaya kepemimpinan partisipatif yang digunakan oleh Kepala BLH Kota Palangka Raya dalam pengendalian kebakaran hutan dan lahan.

Berdasarkan masalah dalam pengendalian kebakaran hutan dan lahan di atas, maka penulis akan melakukan kajian mengenai efektivitas? gaya kepemimpinan Kepala BLH dalam mengendalikan kebakaran hutan dan lahan di Kota Palangka Raya.

\section{Kepemimpinan}

Dalam kepemimpinan terdapat hubungan antar manusia, yaitu hubungan mempengaruhi (dari pemimpin), dan hubungan kepatuhankepatuhan para pengikut atau bawahan karena pengaruh kekuasaan pemimpin. Para pengikut terkena pengaruh kekuatan dari pemimpinya sehingga bangkitlah secara spontan rasa ketaatan kepada pemimpin. Kepemimpinan adalah keunggulan seseorang atau beberapa 
individu dalam kelompok, dalam proses mengontrol gejala-gejala sosial.

Teradapat beberapa pengertian tentang kepemimpinan. Menurut Handoko (1995:294) kepemimpinan merupakan kemampuan yang dipunyai seseorang untuk mempengaruhi orang lain agar bekerja mencapai sasaran. Sedangkan menurut Stoner kepemimpinan adalah suatu proses pengarahan dan pemberian pengaruh pada kegiatan-kegiatan dari sekelompok anggota yang saling berhubungan tugasnya (Handoko, 1995:295). Agar para personalia berjalan dengan baik maka antara lain dibutuhkan kepemimpinan yang efektif yaitu suatu kepemimpinan yang menghargai usaha para bawahan, yang memperlakukan mereka sesuai dengan bakat, kemampuan, dan minat masing-masing individu, serta memberi dorongan untuk berkembang dan mengarahkan diri ke arah tercapainya tujuan lembaga pendidikan. Kepemimpinan yang efektif selalu memanfaatkan kerja sama dengan bawahan untuk mencapai cita-cita organisasi.

Seperti disebutkan di atas, pemimpin adalah orang yang mampu menggerakkan pengikut. Artinya, pemimpin tidak berdiri dan bekerja sendiri melainkan membutuhkan pihak lain.

Seseorang baru dapat dinamakan pemimpin apabila ia berhasil menimbulkan pada bawahannya atau pengikutnya perasaan ikut serta, ikut bertanggung jawab terhadap pekerjaan yang sedang dilaksanakan di bawah pimpinannya untuk mencapai tujuan yang diiinginkan melalui pengaruh yang diberikan oleh seorang pemimpin. Dalam mempengaruhi perubahan lingkungannya melalui perubahan budaya maka mengubah pola pikir pemimpin lebih dahulu merupakan hal yang penting. Ada beberapa penyakit dari kepemimpinan (Wibowo, 2010: 251-255), yaitu :

1. Pemimpin yang tidak mendengarkan.

2. Pemimpin yang tidak mempraktikkan apa yang dikatakan.
3. Pemimpin yang mempraktikkan favoritisme.

4. Pemimpin yang mengitimidasi orang lain.

5. Pemimpin yang mendemoralisasi orang lain.

6. Pemimpin yang gagal menciptakan arah.

7. Pemimpin yang tidak mengembangkan orangnya.

8. Pemimpin yang merasa puas dengan dirinya.

\section{Kekuasaan dan Otoritas}

Jika membahas mengenai kepemimpinan maka tidak terlepas juga mengenai pembahasan tentang kekuasaan dan otoritas. Seseorang dapat mempengaruhi atau diikuti orang lain atau sekelompok orang tidak lain karena orang tersebut memperoleh legitimasi dengan memiliki kekuasaan atau otoritas. Dalam organisasi dan lingkungan kepemerintahan, kemampuan untuk mempengaruhi, mendesak dan memotivasi atau mendorong pengikutnya , disamping tempat, penentuan waktu, penggunaan informasi dan efisiensi, didasarkan juga pada kekuasaan sebagai faktor terjadinya pengaruh (Silalahi, 1989).

Kekuasaan melibatkan kapasitas dari satu pihak (agen) untuk mempengaruhi pihak lain. Konsep ini lebih fleksibel untuk digunakan dengan berbagai cara. Selanjutnya, kekuasaan adalah variabel yang dinamis yang berubah bersamaan dengan perubahan kondisi. Sedangkan otoritas melibatkan hak, prerogativ, kewajiban dan tugas yang berkaitan dengan posisi khusus dalam organisasi atau sistem sosial. Otoritas pemimpin biasanya meliputi hak untuk membuat keputusan khusus untu organisasi. Pemimpin yang memiliki wewenang langsung terhadap seorang target mempunyai hak untuk membuat permintaan yang konsisten dengan otoritasnya, seseorang yang menjadi target itu memiliki kewajiban untuk mematuhinya. 


\section{Gaya Kepemimpinan}

Konsepsi kepemimpinan yang efektif juga beragam. Sebagian besar gaya kepemimpinan lebih menekankan pada satu kategori tertentu sebagai dasar utama untuk menjelaskan gaya kepemimpinan yang efektif. Kurt Lewin menyebut tiga gaya kepemimpinan. Pertama, otokratik yaitu gaya kepemimpinan berpusat pada seorang pemimpin sebagai penentu segala keputusan dan anak buah tidak mempunyai hak untuk berpendapat. Anak buah hanya menjalankan instruksi yang diberikan. Pola komunikasi terjadi satu arah dari pemimpin ke anak buah. Dengan pola kepemimpinan ini, semua tugas yang diberikan harus diselesaikan karena pemimpin memastikan semuanya berjalan sesuai yang diperintahkan. Pemimpin yang menggunakan gaya ini sangat task oriented sehingga besar kemungkinan ada anak buah yang tidak cocok bahkan beberapa diantara mereka menilai gaya kepemimpinan ini terlalu kejam.

Kedua, demokratik yaitu gaya kepemimpinan yang memberikan tanggung jawab dan wewenang kepada semua anggota tim sesuai dengan tugas dan fungsi masingmasing. Semua terlibat aktif dalam mengambil keputusan dan boleh memberikan masukan kepada anggota maupun kepada pimpinan. Pemimpin bersikap terbuka kepada usul yang diberikan karena menganggap semua usul baik adanya untuk kemajuan perusahaan. Pemimpin merasa bahwa semua anggota pasti mempunyai kelebihan dan merupakan pribadi yang unik. Gaya kepemimpinan ini menyeimbangkan antara tugas yang diberikan harus terselesaikan dengan baik dan penting menjaga hubungan harmonis antar anggota tim.

Ketiga, laissez-faire yaitu gaya kepemimpinan yang memberikan kebebasan mutlak kepada anak buah untuk berkreasi. Dalam hal ini, pemimpin bersifat pasif dan menunggu semuanya dari anak buah. Pola kepemimpinan yang terjadi adalah satu arah dari anak buah kepada pimpinan. Gaya kepemimpinan ini cocok diterapkan jika mempunyai anak buah dengan inisiatif yang baik. Pemimpin hanya memberikan arahan singkat berupa tujuan umum saja dan selebihnya diberikan kepada anak buah. Pembagian tugas dan kelompok juga diserahkan kepada anak buah.

Sedangkan menurut House (1971), terdapat empat macam gaya kepemimpinan. Pertama kepemimpinan direktif yang memberikan panduan kepada para pegawai mengenai apa yang seharusnya dilakukan dan bagaimana cara melakukannya, menjadwalkan pekerjaan dan mempertahankan standar kinerja. Kedua, kepemimpinan suportif yang menunjukkan kepedulian terhadap kesejahteraan dan kebutuhan karyawan, bersikap ramah dan dapat didekati serta memperlakukan para pekerja sebagai orang yang setara dengan dirinya. Selanjutnya, kepemimpinan partisipatif atau Konsultatif. Berkonsultasi dengan para karyawan dan secara serius mempertimbangkan gagasan mereka pada saat pengambilan keputusan. Terakhir, kepemimpinan yang berorientasi pada pencapaian dengan menetapkan tujuan yang menantang untuk mendorong para karyawan berprestasi pada tingkat tertinggi mereka untuk menghasilkan kesempurnaan yang bisa membangkitkan kepercayaan diri para karyawan akan kemampuan mereka.

Pendapat yang dikemukakan House tersebut di atas sejalan dengan pendapat yang dikemukan oleh Gibson, Ivancevich, dan Donnelly (2000) yang juga mengemukakan PathGoal theory dan membagi empat kepemimpinan yaitu kepemimpinan direktif, kepemimpinan suportif, kepemimpinan partisipatif dan kepemimpinan orientasi prestasi.

Selain itu, terdapat juga gaya kepemimpinan partisipatif yang mencakup aspek-aspek kekuasaan seperti bersamasama menanggung kekuasaan, pemberian kekuasaan dan proses mepengaruhi yang 
timbal balik. Sedangkan yang menyangkut aspek-aspek perilaku kepemimpinan seperti prosedur-prosedur spesifik yang digunakan untuk berkonsultasi dengan orang lain untuk memperoleh gagasan dan saran-saran, serta perilaku spesifik yang digunakan untuk proses pengambilan keputusan dan pendelegasian kekuasaan.

Yukl (2010) menyebut bahwa kepemimpinan partisipatif menyangkut usahausaha seorang pemimpin untuk mendorong dan memudahkaan partisipasi orang lain dalam membuat keputusan. Partisipasi memiliki banyak bentuk, dimulai dari melakukan revisi keputusan tentatif setelah menerima protes, meminta saran sebelum membuat keputusan, meminta seseorang atau kelompok untuk bersama-sama membuat suatu keputusan, mengizinkan orang lain untuk mebuat suatu keputusan bergantung pada persetujuan akhir pemimpin. Mengikutsertakan orang lain dalam membuat keputusan sering merupakan kebutuhan agar keputusan tersebut diterima dan diimplementasikan. Manfaat dari kepemimpinan partisipatif itu sendiri adalah untuk menghasilkan kualitas keputusan yang lebih baik dan penerimaan keputusan lebih besar oleh orang yang akan menerapkannya. Kepemimpinan partisipatif berarti bahwa berbagai bentuk partisipasi efektif pada situasi tertentu, tetapi tidak pada waktu lainnya. Yang perlu diingat adalah bahwa partisipasi tidak mungkin efektif jika partisipan potensial tidak memiliki sasaran yang sama dari pemimpin tersebut, jika mereka tidak ingin menerima tanggung jawab untuk membantu dalam pengambilan keputusan serta tidak mempercayai pemimpin tersebut.

Terdapat empat prosedur pengambilan keputusan dalam kepemimpinan partisipatif. Pertama, keputusan yang otokratis, pemimpin membuat keputusan sendiri tanpa menanyakan pendapat atau saran dari orang lain, dan orangorang tersebut tidak mempunyai pengaruh langsung terhadap keputusan itu karena tidak ada partisipasi. Kedua, konsultasi dimana pemimpin menanyakan pendapat dan gagasan, kemudian mengambil keputusannya sendiri setelah mempertimbangkan saran dan masukan secara serius. Ketiga, keputusan bersama dimana pemimpin bertemu dengan orang lain untuk mendiskusikan masalah dan mengambil keputusan bersama sehingga keputusan akhir tidak semata menjadi beban pemimpin atau partisipan lainnya melainkan menjadi keputusan bersama. Keempat, pendelegasian dimana pemimpin memberikan otoritas dan tanggung jawab membuat keputusan kepada seseorang atau kelompok dengan memberikan batas waktu tertentu bagi penetapan keputusan akhir.

Yukl (2010) menambahkan bahwa kepemimpinan partisipatif mengandung beberapa hal positif yang diperoleh dari adanya proses yang partisipatif. Dalam hal kualitas keputusan, melibatkan orang lain dalam proses pembuatan keputusan akan berdampak positif terhadap kualitas keputusan mengingat para partisipan bisa jadi memiliki informasi dan pengetahuan yang tidak dimiliki oleh pemimpin sehingga kerja sama banyak pihak akan menemukan solusi yang baik atas masalah yang dihadapi. Dalam hal tingkat penerimaan terhadap suatu keputusan, proses yang partisipatif bisa mengurangi ketakutan dan kecemasan yang tidak beralasan dari suatu keputusan.. Selain itu, akan diperoleh kepuasaan terhadap proses keputusan karena pihak yang terkait dengan kepetusan tersebut memandang bahwa mereka diperlakukan dengan bermartabat dan rasa hormat dengan adanya kesempatan untuk terlibat dalam proses kebijakan yang akan berdampak terhadap mereka. Dampak positif lainnya adalah pengembangan keterampilan partisipan melalui keterlibatan mereka dalam semua aspek proses keputusan sehingga mereka bisa belajar lebih banyak daripada hanya berpartisipasi dalam beberapa aspek proses saja. 


\section{Metode Penelitian}

Penelitian yang dilakukan bermaksud untuk menganalisa kepemimpinan Kepala BLH Kota Palangka Raya dalam pengendalian kebakaran hutan dan lahan. Karenanya, peneliti menganalisa data yang berhubungan dengan tujuan tersebut. Untuk itu, metode yang digunakan dalam penelitian ini adalah metode kualitatif-deskriptif.

Metode penelitian kualitatif-deskriptif digunakan untuk mendeskripsikan fenomenafenomena yang ada, baik fenomena alamiah maupun fenomena buatan manusia. Dalam penelitian deskriptif, bias harus diperkecil dan keterpercayaannya harus dimaksmalkan. Penelitian kualitatif adalah suatu pendekatan penelitian yang mengungkap situasi sosial tertentu dengan mendeskripsikan kenyataan secara benar, dibentuk oleh kata-kata berdasarkan teknik pengumpulan dan analisis data yang relevan yang diperoleh dari situasi alamiah (Satori; Komariah, 2010:25). Penelitian kualitatif memiliki kekuatan seperti yang dinyatakan Maxwell: "The strengths of qualitative research derive primarily from its inductive approach, its focus on specific situations or people, and its emphasis on words rather than numbers" (Maxwell,1996:17).

Teknik sampling adalah teknik pengambilan sampel. Penulis menggunakan teknik purposive sampling yaitu teknik pengambilan sampel sumber data dengan pertimbangan tertentu (Sugiyono, 2009:218219). Informan dalam penelitian ini dipilih berdasarkan pertimbangan-pertimbangan sebagai berikut:

1. Informan memiliki otoritas dalam kaitannya dengan kepemimpinan partisipatif dalam pengendalian kebakaran hutan dan lahan.

2. Informan dianggap memiliki informasi yang banyak mengenai kepemimpinan partisipatif dalam pengendalian kebakaran hutan dan lahan.

3. Adapun yang ditentukan menjadi informan adalah, a) Kepala Badan Lingkungan Hidup Kota Palangka Raya

b) Kepala Bidang Pencegahan dan pengendalian kerusakan lingkungan

c) Kepala Sub Bidang Pencegahan dan Pengendalian kerusakan lingkungan

Dengan demikian, data yang digunakan dalam tulisan ini berasal dari informasi atau hasil wawancara dengan para informan yang telah ditetapkan tersebut di atas serta hasil pengamatan peneliti di lapangan selama tiga bulan masa penelitian yaitu periode Juli hingga September tahun 2014 di Kota Palangka Raya.

\section{Pembahasan}

BLH Kota Palangka Raya merupakan Badan yang ditunjuk langsung berdasarkan Peraturan Daerah Nomor 7 tahun 2003 sebagai lembaga yang terlibat melakukan pengendalian kebakaran hutan dan lahan. Hal ini terkait dengan fungsi BLH Kota Palangka Raya terkait pengendalian kerusakan lingkungan hidup khususnya akibat kebakaran hutan dan lahan.

Sedangkan tugas dan fungsi Kepala Badan Lingkungan Hidup menurut Peraturan Walikota Palangka Raya Nomor 17 Tahun 2012 adalah merumuskan kebijakan operasional badan, mengendalikan, membina, mengatur, mengkoordinasikan dan memberikan pelayanan teknis di bidang penanganan lingkungan hidup secara terpadu bersamasama instansi atau pihak terkait sesuai dengan ketentuan dan perundang-undangan yang berlaku. Adapun fungsi yang dimiliki dari Badan Lingkungan Hidup Kota Palangka Raya adalah sebagai berikut:

(a) Merencanakan dan menyusun kebijakan Badan berdasarkan Peraturan dan perundang-undangan yang berlaku.

(b) Mengendalikan pelaksanaan kegiatan di Badan Lingkungan Hidup berdasarkan pedoman dan ketentuan yang berlaku. 
(c) Merumuskan kebijakan teknis dalam bidang pengelolaan, pengendalian dan pencegahan, pencemaran, kerusakan, pemulihan serta pelestarian lingkungan hidup.

(d) Menyelenggarakan penyuluhan dan pengembangan peran serta masyarakat dalam pelestarian lingkungan.

(e) Mengevaluasi perkembangan penyelenggaraan kegiatn dan program di Bidang Lingkungan Hidup untuk skala prioritas dalam penyelenggaraannya dan program.

(f) Melakukan koordinasi dengan instansi terkait untuk kelancaran pelaksanaan tugas.

Struktur Organiasi Badan Lingkungan Hidup Kota Palangka Raya berdasarkan keputusan Walikota Palangka Raya Nomor 11 Tahun 2008 terdiri dari Kepala Badan, Sekertaris, Bidang Analisis dan Evaluasi Dampak Lingkungan, Bidang Pencegahan dan Pengendalian kerusakan lingkungan, Bidang pengawasan dan penegakan Hukum, dan Bidang Pelestarian Lingkungan Hidup.

Badan Lingkungan Hidup Kota Palangka Raya adalah unsur pelaksana pemerintah Kota Palangka Raya di bidang lingkungan hidup yang dipimpin oleh seorang Kepala Badan yang berkedudukan dibawah dan bertanggung jawab kepada Walikota melalui Sekertaris Daerah. Badan Lingkungan Hidup Kota Palangka Raya mempunyai tugas membantu Walikota dalam melaksanakan pemerintahan dan pembangunan di bidang lingkungan hidup serta tugas pembantuan dan dekonsentrasi yang diberikan oleh Pemerintah Pusat.

\section{Kepemimpinan Partisipatif Kepala BLH Kota Palangka Raya}

Setiap individu merupakan bagian dari kelompok, karena di dalam kelompok tersebut ia dipengaruhi oleh orang lain dan oleh lingkungannya, namun sekaligus ia juga mempengaruhi orang lain dan lingkungan sekitarnya. Sehubungan dengan hal tersebut peran kepemimpinan merupakan suatu hal yang penting dalam rangka mengembangkan kelompok. Kepemimpinan adalah kekuasaan untuk mempengaruhi seseorang, baik dalam mengerjakan sesuatu atau tidak mengerjakan sesuatu. Tugas utama seorang pemimpin adalah mengambil keputusan. Segala sesuatu yang terjadi di dalam organisasi atau yang dilakukan anggota organisasi sebaiknya diputuskan bersama secara partisipatif. Tipe Kepemimpinan itu sendiri adalah gaya atau corak kepemimpinan yang dibawakan oleh seorang pemimpin dalam mempengaruhi para pengikutnya.

Gaya kepemimpinan partisipatif Kepala Badan Lingkungan Hidup Kota Palangka Raya ditandai dengan komunikasi dua arah dalam membina, mengatur dan mengkoordinasikan upaya pengendalian kebakaran hutan dan lahan serta dalam pengambilan keputusan yang turut melibatkan pegawai. Hal tersebut terlihat pada saat rapat untuk menetapkan kebijakan, dimana selalu melibatkan perwakilan tiap seksi untuk menghadiri rapat dan menanyakan kepada perwakilan tiap seksi mengenai masalahmasalah yang terjadi dan mendiskusikannya bersama untuk mendapatkan solusi yang terbaik. Gaya kepemimpinan partisipatif Kepala Badan Lingkungan Hidup Kota Palangka Raya pun mempunyai hubungan yang positif dengan motivasi kerja para pegawai hal ini terlihat dari tidak ada pegawai yang mempunyai motivasi rendah di BLH. Walaupun hanya beberapa pegawai yang memandang atasannya mempunyai gaya kepemimpinan partisipatif.

Kepala BLH Kota Palangka Raya berusaha mendengarkan pandangan yang menolak tanpa menjadi marah-marah. Namun, sekalipun Kepala BLH memposisikan dirinya dalam keadaan netral diantara partisipan namun beberapa pegawai masih ada yang takut untuk mengungkapkan kritik terhadap gagasan dari 
pegawai lain atau keputusan yang diambil . Oleh sebab itu, dalam hal ini Kepala BLH bisa melakukan konsultasi untuk dapat mendorong keyakinan pegawai dalam mengungkapkan pandangan-nya, kritik atau penolakan terhadap gagasan dari partisipan lain atau keputusan yang telah diambil. Motivasi dalam mengemukakan kritik dan penolakan terhadap keputusan atau gagasan yang dikemukakan harus di dorong oleh Kepala BLH Kota Palangka Raya. Tidak selalu penolakan dan kritik adalah hal yang negatif dan menjadi ancaman terhadap sebuah gagasan atau keputusan. Sebaliknya, penolakan dan kritik tersebut dapat menjadi kekuatan untuk menghasilkan keputusan yang berkualitas.

Namun, kenyataannya pada saat pengambilan keputusan seringkali usulan atau pendapat saat diadakan rapat dari partisipan telah dianggap sebagai suatu yang sah karena diminta mengutarakan dan memiliki kesempatan untuk mengemukanan pendapat atau masukan dari partisipan yang memberikan pendapat maupun kritik. Anggapan bahwa pendapat atau masukan yang diberikan telah diterima tersebut akan membuat anggota atau pihak yang memberikan pendapat dalam pengambilan keputusan akan merasa yang menjadi pandangan dan pendapatnya telah benar sehingga akan mengesampingkan pendapat pihak lain. Hal ini berakibat pada anggota organisasi itu sendiri yang dalam pelaksanaan tugasnya berdasarkan pemahaman dan pemikirannya pribadi yang dianggap benar oleh dirinya sendiri. Dalam hal ini seharusnya Kepala BLH Kota Palangka Raya harus menekankan bahwa selama belum ada keputusan akhir yang secara sah dan disetujui bersama maka keputusan tersebut masih bersifat sementara atau tentatif dan memberikan batasan bahwa tidak semua pendapat dan tidak selalu partisipasi dari para anggota organisasi harus dilibatkan karena Kepala BLH memiliki kekuasaan absolut untuk menentukan dan mengambil keputusan tanpa ada pengaruh atau intervensi dari partisipasi anggota organisasi tanpa menyalahi aturan yang ada dan merugikan pihak lain.

Gaya kepemimpinan partisipatif Kepala BLH Kota Palangka Raya tersebut sejalan dengan pendapat yang dikemukan oleh Yukl (2010), bahwa kepemimpinan partisipatif menyangkut usaha-usaha seorang pemimpin untuk mendorong dan memudahkaan partisipasi orang lain dalam membuat keputusan yang jika tidak demikian maka akan dibuat sendiri oleh pimpinan.

Selanjutnya Yukl menjelaskan bahwa pengambilan keputusan dalam kepemimpinan partisipatif tidak berarti bahwa setiap pendapat terkait pengambilan keputusan harus selalu diterima dan setiap pendapat yang disampaikan secara sah dinyatakan sebagai sebuah keputusan karena perlu adanya kesepakatan bersama dan tinjauan atas pendapat yang diberikan dengan kesesuaian untuk masalah guna mendukung keputusan yang ideal dalam pengendalian kebakaran hutan dan lahan. Selain itu, pengambilan keputusan dalam kepemimpinan partisipatif mungkin berarti bahwa berbagai bentuk partisipasi pegawai BLH dalam pengendalian kebakaran hutan dan lahan itu efektif pada situasi tertentu, namun tidak demikian pada waktu lainnya. Karena tidak selalu keputusan dalam pengendalian kebakaran hutan dan lahan harus diputuskan dengan melibatkan partisipan oleh Kepala BLH Kota Palangka Raya. Hal terpenting yang perlu diingat adalah bahwa partisipasi tidak mungkin efektif jika partisipan potensial tidak memiliki sasaran yang sama dalam pengendalian kebakaran hutan dan lahan dari Kepala BLH Kota Palangka Raya, jika mereka tidak ingin menerima tanggung jawab untuk membantu dalam pengambilan keputusan, dan tidak mempercayai pimpinan tersebut.

\section{Kesimpulan}

Berdasarkan hasil pembahasan tersebut di atas dapat ditarik kesimpulan bahwa tugas utama Kepala BLH adalah mengambil 
keputusan yang dilakukan secara partisipatif dalam melaksanakan tugas dan fungsi pengendalian kebakaran hutan dan lahan. Namun perlu diingat bahwa kepemimpinan partisipatif mungkin berarti bahwa berbagai bentuk partisipasi itu efektif pada situasi tertentu, namun tidak demikian pada waktu lainnya. Yang perlu diingat adalah bahwa partisipasi tidak mungkin efektif jika partisipan potensial tidak memiliki sasaran yang sama jika anggota organisasi dalam BLH tidak ingin menerima tanggung jawab untuk membantu dalam pengambilan keputusan, dan tidak mempercayai Kepala BLH sebagai pemimpin.

Adapun saran yang dapat dikemukakan berdasarkan kajian ini yaitu sebagai Kepala BLH Kota Palangka Raya sebaiknya tetap mempertahankan gaya kepemimpinan partisipatif yang sudah ada, namun gaya kepemimpinan tersebut disesuaikan dengan situasi yang ada pada lingkungan kerja. Kepala BLH Kota Palangka Raya diharapkan dapat mempertahankan kondisi motivasi kerja karyawan dengan menciptakan kebersamaan antar karyawan guna menjaga kemeratan sesama karyawan maupun atasan.

\section{Daftar Pustaka}

Akbar, Acep. (2012). Pencegahan Kebakaran Hutan Rawa Gambut Berbasis Masyarakat
(Studi kasus di hutan konservasi Mawas, Kalimantan Tengah). Yogyakarta : UGM. James Gibson, Ivancevich, John M, dan Donnelly James H. (2000). Organizations: Behavior, Structure, Processes. Boston: Irwin McGraw-Hill.

Handoko, T. Hani. (1995). Manajemen Personalia dan Sumber Daya Manusia. Yogyakarta: BPFE.

House, R.J. (1971). A Path Goal Theory of Leader Effectiveness. Administrative Science Quarterly, 16, hlm. 321-338.

Mawardi, Ikhwanuddin, dan Sudaryono. (2008). Konservasi Hutan dan Lahan Melalui Pemberdayaan Masyarakat Sekitar Hutan. Jakarta.

Maxwell, Joseph A. 1996. Qualitative Research Design an Interactive Approach. California: Sage Publications,Inc.

Rusmond, Yunyta. (2008). Implementasi Peraturan

Daerah Provinsi Kalimantan Tengah Nomor 5

Tahun 2003 Tentang Pengendalian Kebakaran Hutan dan Lahan (Studi kasus di Dinas Kehutanan Propinsi Kalimantan Tengah). Malang: Universitas Muhammadiyah.

Djam'anSatori, Komariah, Aan. (2010). Metodologi Penelitian Kualitatif. Bandung: Alfabeta.

Manajemen Kinerja. Edisi Ketiga, Jakarta: Penerbit Rajawali Pers.

Yukl, Gary A. (2010). Kepemimpinan dalam Organisasi, Edisi Indonesia. Jakarta : PT.Indeks. 